\title{
PENGEMBANGAN PEMBELAJARAN MATEMATIKA DENGAN MEMASUKKAN NILAI-NILAI ISLAMI PADA MATERI BILANGAN BULAT
}

\author{
Lisanul Uswah Sadieda' , Ainur Rif atin² \\ ${ }^{1,2)}$ Program Studi Pendidikan Matematika, UIN Sunan Ampel Surabaya \\ ${ }^{1)}$ lisanuluswah@yahoo.com, ${ }^{2)}$ ainurriefhatin@gmail.com
}

\begin{abstract}
Mathematics is a basic science that not only teaches numbers, but in the learning process also trains logical, analytical, systematic and critical thinking ability that useful to whet intellectual. Mathematics can also be a means of instilling Islamic values to students early on to whet their spiritual intelligence in amid the rapid development of the times which leaves the negative impact that is moral decadence. Therefore the aim of this study was to determine how the validity, practicality and effectiveness of the mathematics learning sets by entering the Islamic values in the subject matter of integers at fourth grade MI Mambaul Ulum Terik Krian Sidoarjo. This type of research is the development research using 4-D models of Thiagarajan which consists of four stages which are limited to the stage of develop (development). The results showed that the learning sets are valid, practical and effective. The validity of RPP at 3.93 , the validity of textbooks at 3.65 , and the validity of LKS at 3.73. The learning sets meets the criteria of practical learning with an average of 3 . While the effectiveness criteria are met due to the activity of teachers at 3.36 , active student activities as much as $63.33 \%$, mastery learning students by $77.78 \%$, and the positive response of students at $80.56 \%$.
\end{abstract}

Keywords: teaching Islamic values, integers

\section{PENDAHULUAN}

Perkembangan dan kemajuan zaman yang semakin pesat saat ini membawa dampak positif dan negatif bagi kehidupan, termasuk dalam dunia pendidikan. Di satu sisi terdapat pencapaian kemajuan teknologi yang luar biasa seperti kemudahan mengakses informasi melalui internet yang dapat membuat pendidikan berjalan lebih optimal. Namun, di sisi lain jika kemajuan teknologi itu tidak diimbangi dengan penanaman nilai-nilai agama, salah satunya adalah nilai-nilai islami, maka kemajuan teknologi akan berdampak buruk khususnya bagi dunia pendidikan sendiri, karena bisa menyebabkan para peserta didik malas belajar, individualis, egois, acuh tak acuh, tidak disiplin, yang semua itu bisa menjerumuskan ke dalam keburukan yang lebih jauh.

Oleh karena itu, pendidikan harus mampu menjawab tantangan dampak negatif kemajuan zaman tersebut dengan cara memasukkan nilai-nilai islami dalam setiap pembelajaran, sebab pendidikan tidak hanya memiliki tugas meningkatkan kemampuan peserta didik dari sisi intelektual, namun juga memegang peranan yang sangat penting dalam menciptakan manusia berkualitas dari sisi mental, karakter, dan kepribadian. Hal itu sesuai dengan UU No. 20 tahun 2003 tentang Sistem Pendidikan Nasional, yang menyebutkan bahwa pendidikan nasional bertujuan untuk berkembangnya potensi peserta didik agar menjadi manusia yang beriman dan bertakwa kepada Tuhan Yang Maha Esa, berakhlak mulia, sehat, berilmu, cakap, kreatif, mandiri, dan menjadi warga negara yang demokratis serta bertanggung jawab (Wina, 2008), maka nilai-nilai islami harus benar-benar mampu dimasukkan dalam setiap pembelajaran, tidak hanya dalam pembelajaran agama saja, namun juga pada pembelajaran ilmu pengetahuan umum. 
Di antara ilmu pengetahuan umum yang sangat penting untuk dipelajari dan dikuasai seseorang adalah pelajaran matematika. Sebab, matematika merupakan ilmu dasar yang tidak hanya mengajarkan angka dan jumlah, namun dalam proses pembelajaran metematika juga secara sadar akan dilatihkan kemampuan berpikir logis, analitis, sistematis, dan kritis yang berguna untuk mengasah kecerdasan intelektual. Mengingat manfaat pelajaran matematika yang sangat baik dan dibutuhkan dalam hidup sebagai salah satu ilmu dasar, maka pelajaran ini juga bisa menjadi sarana untuk menanamkan nilai-nilai islami kepada peserta didik sejak dini, sehingga melalui pembelajaran matematika ini peserta didik dapat mengasah kecerdasan intelektual sekaligus kecerdasan spiritualnya dengan cara menghadirkan contoh-contoh akhlak mulia yang telah sering diajarkan dalam keluarga dan di tengah kehidupan bermasyarakat.

Dari penjelasan di atas, maka penulis tertarik melakukan penelitian untuk menjawab permasalahan bagaimana kevalidan, kepraktisan dan keefektifan perangkat pembelajaran matematika dengan memasukkan nilai-nilai islami pada materi pokok bilangan bulat kelas IV MI Mambaul Ulum Terik Krian Sidoarjo?

\section{KAJIAN TEORI}

\section{Pembelajaran dengan Memasukkan Nilai-nilai Islami}

Pembelajaran ini berangkat dari metode pembelajaran matematika qurani yang dalam proses pembelajarannya selalu mengikutsertakan ayat-ayat al-Quran dan al-Hadits yang mempunyai nilai moral.

Nilai adalah suatu konsep yang berada dalam pikiran manusia yang sifatnya tersembunyi, tidak berada di dalam dunia yang empiris. Nilai berhubungan dengan pandangan seseorang tentang baik dan buruk, indah dan tidak indah, layak dan tidak layak, adil dan tidak adil, dan lain sebagainya (Wina, 2008). Yang dalam hal ini, semua itu berdasarkan dua sumber utama pengambilan nilai-nilai islam yaitu al-Quran dan al-Hadits.

Al-Quran secara terminologi adalah kalam Allah SWT. yang diturunkan kepada Rasul dan penutup para Nabi-Nya, Muhammad SAW., diawali dengan surat al-Fatihah dan diakhiri dengan surat an-Naas (Alilmu, 2007). Para ahli (alim ulama) telah mengemukakan beberapa definisi al-Quran, antara lain mengatakan bahwa al-Quran adalah firman Allah SWT. yang berfungsi mu'jizat, diturunkan kepada Nabi Muhammad SAW., tertulis dalam mushaf, diriwayatkan dengan jalan mutawatir dan dipandang beribadat membacanya (Hajisunaryo, 2007)."

Sedangkan al-Hadits secara terminologi adalah segala sesuatu yang disandarkan kepada Nabi Muhammad SAW. baik berupa perkataan, perbuatan, pernyataan (taqrir), dan sebagainya. Al-Hadits kadangkadang juga disebut al-Sunnah dan keduanya juga dipergunakan saling bergantian untuk maksud yang sama.

Dari penjelasan di atas dapat disimpulkan bahwa nilai-nilai al-Quran adalah suatu konsep yang sifatnya tersembunyi, yang diturunkan oleh Allah SWT. kepada Nabi Muhammad SAW. agar digunakan sebagai petunjuk umat Islam di dunia dan akhirat. Sementara al-Hadits adalah semua yang berasal dari Nabi Muhammad saw baik berupa perkataan, perbuatan, atau ketetapannya dan disampaikan secara lisan maupun tulisan.

Dalam pembelajaran ini, yang dimaksud nilai-nilai islami adalah suatu konsep nilai-nilai kebaikan yang terdapat di dalam al-Quran dan al-Hadits serta dapat digunakan sebagai pedoman untuk belajar matematika pada materi pokok bilangan bulat. Adapun beberapa nilai-nilai islami yang digunakan adalah sebagai berikut:

a. Bermusyawarah. Dalam pembelajaran saling memaafkan dan bermusyawarah akan lebih cepat menyelesaikan masalah yang diberikan oleh guru. Hal ini sesuai dengan firman Allah SWT dalam surat Ali Imran ayat 159 yang mempunyai arti: "Maka disebabkan rahmat dari Allah-lah kamu berlaku lemah lembut terhadap mereka. Sekiranya kamu bersikap keras lagi berhati kasar, tentulah mereka menjauhkan diri dari sekelilingmu. Karena itu ma'afkanlah mereka, mohonkanlah ampun bagi mereka, dan bermusyawarahlah dengan mereka dalam urusan itu. Kemudian apabila kamu telah membulatkan tekad, maka bertawakkallah kepada Allah. Sesungguhnya Allah menyukai orang-orang yang bertawakkal kepada-Nya."

b. Amanah, yaitu terpercaya dan mampu menepati janji. Sesuatu yang dipercayakan kepada seseorang baik berupa tugas, titipan harta, rahasia, dan amanat lainnya, mesti dipelihara dalam arti dilaksanakan sebagaimana mestinya. Ketika pembelajaran, apabila siswa mengerjakan tugas yang diberikan oleh guru maka siswa tersebut termasuk dalam yang terpercaya dan mampu menepati janji karena telah bertanggung jawab terhadap tugas yang diberikan. Allah swt. berfirman dalam surat al-Mu'minun ayat 8 yang berarti: "Dan orang-orang yang memelihara amanat-amanat (yang dipikulnya) dan janjinya."

c. Anisatun, yaitu manis muka dan tidak sombong. Selalu membiasakan manis muka kemungkinan kita tidak dianggap orang sombong. Sedangkan orang sombong itu tidak disukai Allah swt dan juga manusia. Jika kita membiasakan bermanis muka dan tidak sombong dalam proses pembelajaran, kita tidak akan mudah marah karena banyak teman. Allah swt berfirman dalam surat 
Luqman ayat 18, yang mempunyai arti: "Dan janganlah kamu memalingkan mukamu dari manusia (karena sombong) dan janganlah kamu berjalan di muka bumi dengan angkuh. Sesungguhnya Allah tidak menyukai orang-orang yang sombong lagi membanggakan diri."

d. Al-ikhwan dan al-Ishlah, yaitu persaudaraan atau perdamaian. Belajar dalam kelompok akan membangun rasa persaudaraan dan perdamaian. Allah swt berfirman dalam surat al-Hujurat ayat 10. Yang berarti:: "Orang-orang beriman itu sesungguhnya bersaudara. Sebab itu damaikanlah (perbaikilah hubungan) antara kedua saudaramu itu dan takutlah terhadap Allah, supaya kamu mendapat rahmat." (Muslimah, 2007)

Selain nilai-nilai islami yang membahas tentang akhlak di atas, juga dimasukkan nilai-nilai islami lainnya yang dapat digunakan sebagai pedoman untuk belajar matematika pada materi pokok bilangan bulat seperti:

a. Berbuat kebaikan dan menghindari perbuatan buruk. Hal ini bisa digunakan sebagai sarana untuk menanamkan salah satu konsep pembelajaran dalam materi pokok bilangan bulat. Nabi Muhammad saw. bersabda yang artinya: “... Dan ikutilah keburukan (yang kamu lakukan) dengan kebaikan, karena kebaikan itu akan menghapus keburukan ..." (HR. Bukhori)

b. Tampil sebaik mungkin saat ke masjid. Hal ini digunakan untuk memberi contoh penanaman salah satu konsep lainnya dalam pembelajaran materi pokok bilangan bulat. Allah swt. berfirman dalam Q.S. al-A'rof ayat 31 yang artinya: "Hai anak Adam, pakailah pakaianmu yang indah di setiap (memasuki) mesjid, makan dan minumlah, dan janganlah berlebih-lebihan. Sesungguhnya Allah tidak menyukai orang-orang yang berlebih-lebihan."

\section{Bilangan Bulat dan Operasi Bilangan Bulat dalam al-Qur' an}

Bilangan bulat antara lain terdapat dalam surat al-Ikhlas ayat 1 yang mempunyai arti: Katakanlah: "Dia-lah Allah, yang Maha Esa.

Dan juga di dalam surat at-Taubah ayat 40 yang berarti: "Jikalau kamu tidak menolongnya (Muhammad) Maka Sesungguhnya Allah telah menolongnya (yaitu) ketika orang-orang kafir (musyrikin Mekah) mengeluarkannya (dari Mekah) sedang Dia salah seorang dari dua orang ketika keduanya berada dalam gua, di waktu Dia berkata kepada temannya: "Janganlah kamu berduka cita, Sesungguhnya Allah beserta kita." Maka Allah menurunkan keterangan-Nya kepada (Muhammad) dan membantunya dengan tentara yang kamu tidak melihatnya, dan Al-Quran menjadikan orangorang kafir Itulah yang rendah. dan kalimat Allah Itulah yang tinggi. Allah Maha Perkasa lagi Maha Bijaksana."

Kata yang bercetak tebal pada kedua arti ayat di atas, "Esa (satu)", "seorang", dan "dua" merupakan contoh-contoh bilangan bulat dalam al-Qur'an. Selain itu, terdapat konsep tentang relasi pada bilangan bulat dalam al-Qur' an, seperti pada surat al-Mujadalah ayat 7 yang artinya: "Tidakkah kamu perhatikan, bahwa Sesungguhnya Allah mengetahui apa yang ada di langit dan di bumi? Tiada pembicaraan rahasia antara tiga orang, melainkan Dia-lah keempatnya. dan tiada (pembicaraan antara) lima orang, melainkan Dia-lah keenamnya. dan tiada (pula) pembicaraan antara jumlah yang kurang dari itu atau lebih banyak, melainkan Dia berada bersama mereka di manapun mereka berada. Kemudian Dia akan memberitahukan kepada mereka pada hari kiamat apa yang telah mereka kerjakan. Sesungguhnya Allah Maha mengetahui segala sesuatu."

Kata yang bercetak tebal pada arti ayat di atas yaitu kata "kurang dari" dan "lebih banyak" adalah kata-kata yang selalu digunakan saat membandingkan sesuatu. Ayat lainnya membahas tentang operasi penjumlahan pada bilangan bulat yang terdapat dalam surat al-Kahfi ayat 25 yang artinya: "Dan mereka (Ash-habul Kahfi) tinggal di dalam gua mereka tiga ratus tahun dan ditambah sembilan tahun (lagi)" ( Mushaf Sahmalnour: 96).

Dalam surat ini terdapat penjumlahan bilangan yaitu: $300+Y$.

Operasi pengurangan pada bilangan bulat dapat dilihat dalam al-Quran surat al-Ankabut ayat 14 yang berarti: "Dan sungguh, Kami telah mengutus Nuh kepada kaumnya, maka dia tinggal bersama mereka selama seribu tahun kurang lima puluh tahun maka mereka ditimpa banjir besar, dan mereka adalah orang-orang yang zalim.

Dalam surat tersebut terdapat pengurangan bilangan bulat yaitu: $1000-50$ (Abdussakir, 2009) 


\section{METODE PENELITIAN}

Penelitian ini tergolong jenis penelitian pengembangan. Subyek penelitian adalah 36 orang siswa MI Mambaul Ulum Terik Krian Sidoarjo. Penelitian ini dititikberatkan pada pengembangan perangkat pembelajaran yang meliputi Rencana Pelaksanaan Pembelajaran (RPP), buku ajar, dan Lembar Kerja Siswa (LKS).

Penelitian ini menggunakan model pengembangan 4-D (four-D model) menurut Thiagarajan yang terdiri dari 4 tahap yaitu Define (pendefinisian), Design (perancangan), Develop (pengembangan), dan Disseminate (penyebaran). Akan tetapi, penelitian ini hanya dilakukan sampai pada tahap pengembangan saja karena penelitian ini hanya diuji cobakan satu kali. Berikut ini bagan model pengembangan 4D yang telah dimodifikasi

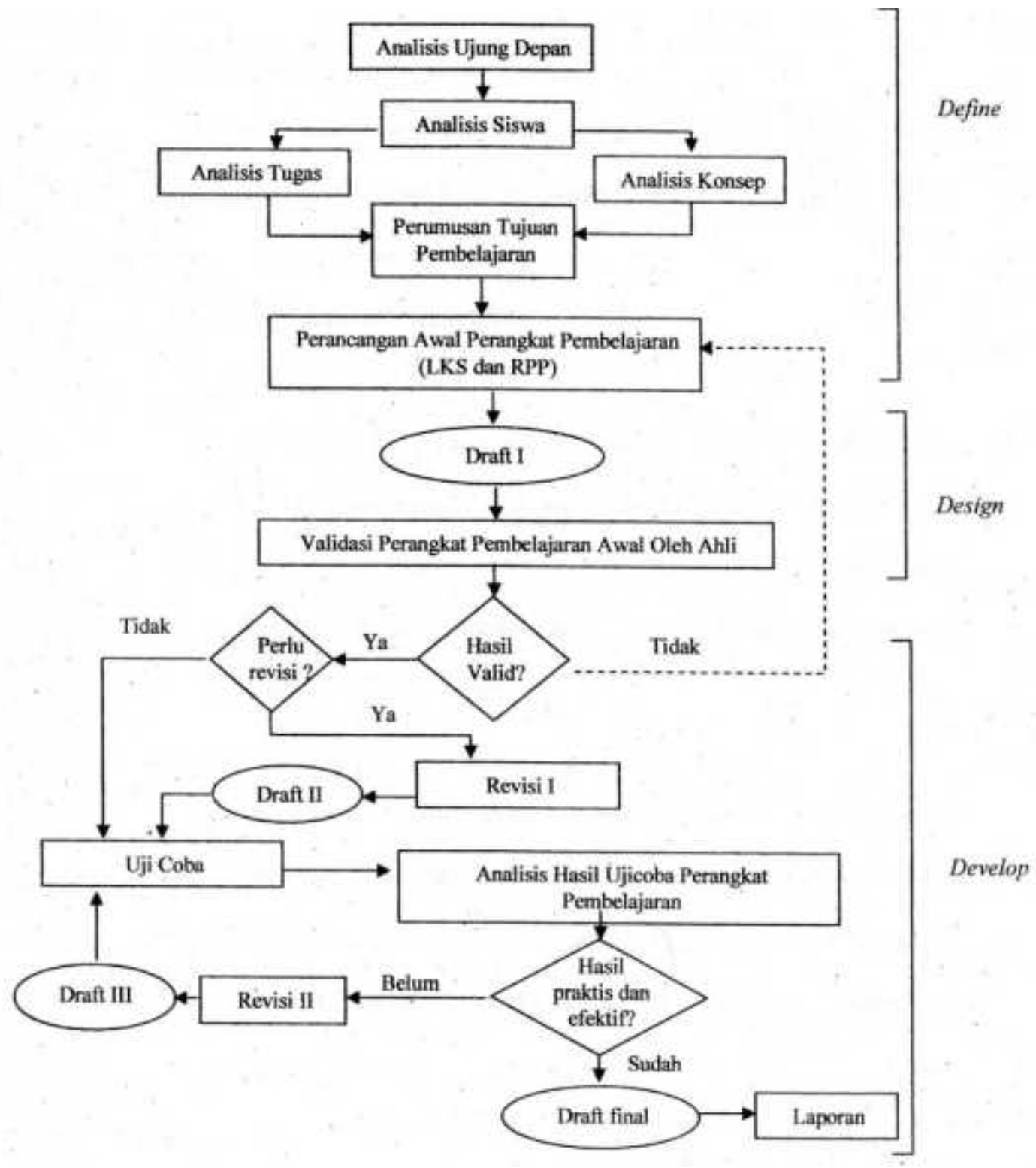

Gambar 1. Model Pengembangan 4D yang Telah Dimodifikasi

Metode pengumpulan data yang digunakan adalah: 1). Metode observasi yang digunakan untuk memperoleh data hasil aktivitas guru dan aktivitas siswa dalam pembelajaran matematika dengan memasukkan nilai-nilai islami. Data aktivitas guru dan aktivitas siswa dicatat dalam lembar pengamatan yang disusun oleh peneliti. Data ini juga digunakan sebagai data pendukung dalam menyimpulkan keefektifan perangkat pembalajaran yang dikembangkan pada materi bilangan bulat. Pengamatan aktivitas guru dilakukan oleh seorang pengamat sedangkan aktivitas siswa diamati oleh dua orang pengamat. Pengamat pertama adalah Zainul Makhsus, S.Pd (Guru MI Mambaul Ulum 
Terik Krian Sidoarjo) yang mengamati 3 orang siswa, sedangkan pengamat kedua adalah peneliti sendiri yang mengamati 2 orang siswa; 2). Metode tes yang diberikan kepada siswa pada akhir pertemuan digunakan untuk memperoleh data ketuntasan hasil belajar siswa setelah kegiatan pembelajaran usai; 3). Metode angket yang digunakan untuk mendapatkan data tentang respon siswa selama pembelajaran matematika dengan memasukkan nilai-nilai islami. Angket diberikan kepada setiap siswa setelah pembelajaran selesai.

Adapun analisis data yang digunakan dijelaskan sebagai berikut: data validasi buku ajar akan dihitung dengan rumus:

1) Mencari rata-rata validasi perkategori dari validator

$$
\boldsymbol{B}_{i}=\frac{\sum_{h=1}^{n} V_{h i}}{n}
$$

Keterangan:

$B_{i}=$ rata-rata validasi perkategori

$V_{h i}=$ skor hasil penilaian validator ke-h untuk kategori ke-i

$n$ = banyak validator

2) Mencari rata-rata validasi dari tiap sub komponen

$$
\boldsymbol{S}_{i}=\frac{\sum_{j=1}^{n} B_{i j}}{\boldsymbol{T}}
$$

Keterangan:

$S_{i}$ = rata-rata validasi per sub komponen

$B_{i j}=$ rata-rata untuk subkomponen ke-i dan kategori ke-j

$n$ = banyak butir dalam sub komponen

3) Mencari rata-rata validasi dari tiap komponen

$\boldsymbol{K}_{i}=\frac{\sum_{j=1}^{n} S_{i j}}{n}$

Keterangan:

$K_{i}=$ rata-rata validasi per komponen

$S_{j i}=$ rata-rata untuk komponen ke-i dan kategori ke-j

$n$ = banyak sub komponen dalam komponen ke-i

4) Mencari rata-rata total validasi semua komponen

$K T V=\frac{\sum_{i=1}^{\sim} K_{i}}{n}$

Keterangan:

$R T V \quad=$ rata-rata total validasi buku ajar

$K_{i} \quad=$ rata-rata validasi per komponen ke-i

$n \quad=$ banyak komponen

menentukan kategori kevalidan dengan mencocokkan rata-rata total dengan kriteria kevalidan buku ajar (Hayana, 2011).

Sangat valid $: 4 \leq K I V \leq 5$

Valid : $3 \leq K T V<4$

Kurang valid $\quad: 2 \leq k T V<3$

Tidak valid $\quad: 1 \leq K T V<2$ 
Sedangkan data validasi RPP dan LKS dihitung dengan rumus:

1) Mencari rata-rata validasi tiap kategori dari semua validator (Sumaryono, 2011).

Keterangan:

$$
R K_{i}=\frac{\sum_{j=1}^{n} V_{j i}}{n}
$$

$R K_{i} \quad=$ Rata-rata validasi kategori ke- $i$

$V_{j i} \quad=$ Skor hasil penilaian validator ke- $j$ untuk butir ke- $i$

$n \quad=$ Banyaknya validator

2) Mencari rata-rata validasi tiap aspek dari semua validator

$$
R A_{i}=\frac{\sum_{f=\mathbf{1}}^{n} R K_{j i}}{n}
$$

Keterangan:

$R A_{i} \quad=$ Rata-rata validasi aspek ke- $i$

$R K=$ Rata-rata kategori ke-j terhadap aspek ke- $i$

$n \quad=$ Banyak kategori dalam aspek ke- $i$

3) Mencari rata-rata total validitas

$$
V K=\frac{\sum_{i=1}^{n} R A_{i}}{n}
$$

Keterangan:

$V R \quad=$ rata-rata total validitas

$R A i \quad=$ rata-rata aspek ke- $i$

$n \quad=$ banyaknya aspek

Menentukan kategori kevalidan dengan mencocokkan rata-rata total dengan kriteria kevalidan perangkat pembelajaran.

$\begin{array}{lll}\text { Sangat valid } & : 4 \leq V K<5 \\ \text { Valid } & : 3 \leq V K<4 \\ \text { Kurang valid } & : 2 \leq V K<3 \\ \text { Tidak valid } & : 1 \leq V K<2\end{array}$

Data kepraktisan perangkat pembelajaran dianalisis dengan kriteria:

4 : dapat digunakan tanpa revisi

3 : dapat digunakan dengan sedikit revisi

2 : dapat digunakan dengan banyak revisi

1 : belum dapat digunakan, masih memerlukan konsultasi

Dikatakan praktis apabila secara teori validator menyatakan perangkat pembelajaran dapat digunakan di lapangan dengan kriteria 3 atau 4.

Perangkat pembelajaran dapat dikatakan efektif jika mencapai indikator-indikator yang ditetapkan yaitu: aktivitas guru baik, aktivitas siswa dalam kategori aktif, hasil belajar siswa memenuhi batas ketuntasan belajar individual yaitu minimal 70 dan klasikal yaitu $71 \%$ dari keseluruhan siswa tuntas, dan respon siswa positif. Analisis masing-masing indikator akan dibahas sebagai berikut: 
Data hasil penelitian pengamat terhadap aktivitas guru selama mengelola pembelajaran dianalisis dengan menghitung nilai rata-rata setiap aspek dari beberapa pertemuan yang dilaksanakan. Kemudian menghitung skor rata-rata dengan menggunakan rumus:

$\bar{x}=\frac{\sum x_{i}}{n}$

Keterangan:

$\bar{x} \quad=$ rata-rata skor kecakapan kemampuan guru

$\sum x_{i} \quad=$ jumlah skor tiap aspek yang diamati

$\boldsymbol{n}=$ banyaknya pertemuan

Selanjutnya nilai tersebut dikonversi dengan kriteria sebagai berikut:

$0,00 \leq \bar{x}<1,50$

$1,50 \leq \bar{x}<2,50$

$2,50 \leq \bar{x}<3.50$

tidak baik

$3,50 \leq \bar{x} \leq 4,00$

kurang baik

baik

Dengan $\bar{x}$ adalah aktivitas guru selama pembelajaran.

Aktivitas guru selama mengelola pembelajaran dikatakan "baik" apabila konversi nilai rata-rata setiap aspek pengamatan yang diberikan oleh dua orang pengamat pada setiap pertemuan berada pada kriteria "baik/sangat baik".

Analisis data hasil pengamatan aktivitas siswa selama proses pembelajaran digunakan rumus sebagai berikut:

aktivitas siswa kategori ke $-\mathrm{n}(\%)=\frac{\sum \text { trekuensi aktivitas siswa ke }- \text { n yang muncul }}{\sum \text { total trekuensi aktivitas siswa ke }- \text { n yang muncul }} \times 100 \%$

Setelah diperoleh hasil dari aktivitas siswa kategori ke-n (\%), untuk menentukan rata-rata persentase aktivitas siswa dalam kegiatan belajar mengajar adalah:

$$
\text { rata }- \text { rata }(\%)=\frac{\sum \text { aktivitas siswa kategori ke }- \text { n yang muncul }}{\sum \text { pertemuan kegiatan belajar mengajar }} \times 100 \%
$$

Aktivitas siswa dikatakan aktif jika Persentase dari setiap aktivitas siswa yang dikategorikan aktif lebih besar daripada aktivitas siswa yang dikategorikan pasif.

Hasil belajar siswa dapat diketahui dari Tes Hasil Belajar (THB). Berdasarkan kurikulum 2006 yang telah diberlakukan di MI Mambaul Ulum Terik Krian Sidoarjo, seorang siswa dinyatakan lulus apabila telah mencapai indikator pembelajaran yang ditetapkan dan dinyatakan lulus secara individual jika mendapatkan nilai $\geq \underset{ }{2}$. Sedangkan keberhasilan kelas (ketuntasan klasikal) dilihat dari jumlah peserta didik yang mampu menyelesaikan sekurang-kurangnya $/ 1 \%$ dari jumlah siswa yang ada di kelas tersebut. Untuk mengetahui ketuntasan klasikal digunakan rumus:

$$
\% \text { ketuntasan klasikal }=\frac{\text { jumlah siswa yany tuntas }}{\text { jumlah seluruh siswa }} \times 100 \%
$$

Analisis terhadap data respon siswa dihitung dengan cara menentukan Persentase tiap-tiap respon siswa. Persentase dihitung dengan menggunakan rumus sebagai berikut:

$$
\text { Persentase respon siswa }=\frac{A}{B} \times 100 \%
$$

Keterangan:

A $\quad=$ Frekuensi jawaban tiap aspek

$\mathrm{B}=$ Banyaknya responden 
Selanjutnya hasil dari perhitungan Persentase tersebut dinyatakan ke dalam kategori respon positif siswa jika Persentase respon positif lebih besar daripada respon negatif.

\section{PEMBAHASAN}

\section{Validitas dan Kepraktisan Perangkat Pembelajaran}

Proses pengembangan perangkat pembelajaran yang terdiri dari RPP, LKS dan Buku Ajar dengan model pengembangan 4D yang telah dimodifikasi ini menghasilkan draft final sebagai berikut:

\section{Rencana Pelaksanaan Pembelajaran (RPP)}

Susunan RPP berorientasi pada pembelajaran matematika dengan memasukkan nilai-nilai islami pada pembelajaran kooperatif yang di dalamnya memuat identitas RPP, alokasi waktu, standar kompetensi, kompetensi dasar, indikator, tujuan pembelajaran, materi prasyarat, sumber belajar, alat dan bahan, serta langkah-langkah pembelajaran. Standar kompetensi dan kompetensi dasar yang digunakan sesuai dengan depenelitian yang terdapat pada kurikulum KTSP untuk kelas IV semester genap. Adapun kegiatan pembelajaran mengacu pada langkah-langkah pembelajaran kooperatif, meliputi penjelasan materi, belajar dalam kelompok, penilaian, dan pengakuan tim. Berikut ini contoh langkah-langkah pembelajaran matematika dengan memasukkan nilai-nilai islami pada materi bilangan bulat:

Tabel 1. Contoh Langkah-Langkah Pembelajaran Matematika dengan Memasukkan Nilai-Nilai Islami Pada Materi Bilangan Bulat

\begin{tabular}{l}
\hline \multicolumn{1}{c}{ Aktivitas Guru } \\
\hline Pendahuluan \\
- Membuka pelajaran dengan salam dan berdo'a \\
bersama membaca Q.S. Al-Fatihah dan do'a akan \\
belajar. \\
- Mengabsen siswa serta menyampaikan indikator \\
pelajaran secara klasikal (dengan cara \\
membacakan). \\
Memotivasi siswa dengan menyampaikan manfaat \\
tentang yang akan dipelajari hari ini dalam \\
kehidupan sehari-hari dengan membacakan Q. S. \\
Al-Ikhlas ayat 1 dan Q. S. At-Taubah ayat 40 \\
beserta artinya yaitu tentang bilangan satu kita \\
dapat mengetahui keesaan Allah swt., dan dapat \\
memahami kisah Nabi Muhammad saw. yang \\
berdua dengan Abu Bakar saat bersembunyi di \\
dalam gua.
\end{tabular}

\section{Kegiatan Inti}

Tahap I (Penjelasan materi)

- Membagikan buku ajar 1. Aktivitas Siswa

- Memberikan gambaran umum tentang materi pelajaran pada buku ajar 1 yang harus dikuasai siswa sesuai dengan Q.S. al-Mujadalah ayat 7.

- Memberikan kesempatan siswa untuk membaca dan memahami materi yang terdapat pada buku ajar 1.

- Memberikan kesempatan bertanya tentang kejelasan materi.

Tahap 2 (Belajar dalam kelompok)

- Membentuk kelompok secara heterogen dimana setiap kelompok terdiri dari 6 orang, dengan cara berhitung mulai dari 1-8 secara berulang ke seluruh siswa, siswa yang mendapat nomor sama berkumpul dan membentuk satu kelompok.

- Menerima buku ajar 1 dari guru.

- Mendengarkan dan memperhatikan penjelasan guru.

Mendengarkan
penjelasan guru.

Menjawab salam dan berdo'a bersama membaca Q.S. Al-Fatihah dan do'a akan belajar.

- Memperhatikan penjelasan guru.$$
\text { penjelasan guru. }
$$

dan memperhatikan

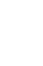

Membaca dan memahami materi yang terdapat pada buku ajar 1 . - Siswa yang belum memahami materi
bertanya kepada guru.

- Berhitung mulai dari 1-8 dan duduk sesuai nomor kelompoknya. 
- Membagikan LKS 1 sebagai panduan kerja kelompok.

- Memberi kesempatan siswa untuk membaca dan memahami masalah pada LKS 1.

- Memberi kesempatan siswa untuk bertanya tentang kejelasan masalah pada LKS 1 .

- Memberi kesempatan kepada siswa untuk menyelesaikan dan mendiskusikan/membandingkan jawaban dengan teman sekelompoknya. Guru berkeliling kelas untuk melihat pekerjaan siswa, jika ada yang kesulitan untuk menyelesaikan masalah maka guru dapat memotivasi siswa dengan memberikan pertanyaan, petunjuk, atau saran.

Tahap 3 (Penilaian)

- Meminta beberapa orang siswa mewakili kelompoknya untuk menampilkan hasil diskusi dan penyelesaian masalahnya di depan kelas. Guru menilai hasil pekerjaan dari masing-masing kelompok.

Tahap 4 (Pengakuan tim)

- Mendorong kelompok lain untuk memberikan tanggapan terhadap hasil pekerjaan kelompok yang maju ke depan. Melalui diskusi kelas guru mengarahkan siswa untuk menyimpulkan dan memberi penghargaan terhadap kelompok yang hasil pekerjaannya paling bagus.

\section{Penutup}

- Membentuk sesi tanya jawab antara guru-siswa dan siswa-siswa.

- Menyampaikan informasi tentang pelajaran yang akan dipelajari pada pertemuan selanjutnya, yaitu tentang penjumlahan bilangan bulat kemudian menutup pelajaran dengan bacaan hamdalah dan salam.

- Menerima LKS 1 dari guru.

- Membaca dan memahami masalah pada LKS 1.

- Siswa yang belum memahami masalah bertanya kepada guru

- Menyelesaikan masalah dan mendiskusikan/membandingkan jawaban dengan teman sekelompoknya.

- Siswa yang telah ditunjuk mewakili kelompoknya maju ke depan kelas untuk mempresentasikan hasil diskusi kelompoknya.

- Memberikan tanggapan terhadap hasil pekerjaan kelompok yang telah maju ke depan. Siswa menyimpulkan dan memberi penghargaan terhadap kelompok yang hasil pekerjaannya paling bagus.

- Tanya jawab dengan guru dan teman.

- Mendengarkan informasi dari guru kemudian membaca hamdalah dan salam.

Berdasarkan hasil analisis data didapatkan rata-rata total dari penilaian para validator sebesar 3,93, sehingga RPP yang dikembangkan termasuk dalam kategori valid. RPP ini juga dinilai praktis oleh validator karena dapat digunakan dengan sedikit revisi.

\section{Lembar Kegiatan Siswa (LKS)}

LKS yang dikembangkan dalam penelitian ini berisi masalah dari buku ajar. Permasalahan yang dipilih adalah permasalahan dalam kehidupan sehari-hari dan sering ditemui oleh siswa serta mempunyai nilai-nilai islami. Pertanyaan-pertanyaan yang diberikan di dalam LKS berfungsi untuk membimbing siswa secara tidak langsung dalam menemukan konsep. Berikut ini adalah contoh permasalahan yang terdapat di LKS: 
Petunjuk untuk soal No. 4: Jawablah pertanyaan nomor 4 dengan tekun sambil menundukkan hati bersama kelompokmu!

4. Jumlah rakaat sholat Subuh adalah 2 rakaat. Sedangkan jumlah rakaat sholat Ashar adalah 4 rakaat. sholat manakah yang jumlah rakaatnya lebih kecil?

Petunjuk untuk soal No. 5: Jawablah pertanyaan nomor 5 dengan sistematis dan saling tolong menolong serta tanamkan rasa persaudaraan di dalam kelompokmu!

5. Dalam bulan Ramadhan tahun lalu Bela berpuasa selama 15 hari, Fitri selama 10 hari, Salwa selama 24 hari, Imel selama 19 hari, Putri selama 30 hari, dan Tiara selama 29 hari.

a. Siapakah yang paling sering melaksanakan ibadah puasa?

b. Siapakah yang paling jarang melaksanakan ibadah puasa?

c. Urutkan mulai dari siapa yang paling jarang melaksanakan ibadah puasa!

d. Urutkan mulai dari siapa yang paling sering melaksanakan ibadah puasa!

Gambar 2. Contoh LKS

Berdasarkan analisis data, LKS dalam pembelajaran matematika dengan memasukkan nilainilai islami yang telah dikembangkan termasuk dalam kategori valid yaitu 3,73 dan memenuhi aspek kepraktisan karena menurut validator dapat digunakan dengan sedikit revisi.

Buku Ajar

Masing-masing isi buku ajar dimulai dengan penjelasan sederhana tentang apa yang akan dipelajari. Halaman pertama buku ajar berisikan standar kompetensi, kompetensi dasar, dan indikator pembelajaran. Dalam buku ajar terdapat situasi matematika berupa cerita dan pertanyaan-pertanyaan yang berguna bagi siswa dalam menyelesaikan masalah yang sesuai dengan pembelajaran matematika dengan memasukkan nilai-nilai islami. Diharapkan dengan adanya buku ajar tersebut, siswa akan belajar langkah demi langkah secara aktif dan terbiasa untuk mengkontruksi pengetahuannya sendiri. Berikut ini merupakan contoh penyajian materi yang memasukkan nilai-nilai islami pada buku ajar:

\section{Konsep bilangan bulat}

Kalian tentu sering melihat bilangan 1, 2, 3, 4, 5, 6, 7, 8, 9, 10, ... Tahukah kalian, ternyata di dalam al-Qur' an juga terdapat ayat-ayat yang menjelaskan bilangan-bilangan, seperti di dalam Al-Qur' an surat Al-Ikhlas ayat 1 yang artinya:

Katakanlah (M uhammad), "Dialah Allah, Yang M aha Esa (Satu)"

Dan juga di surat At-Taubah ayat 40 yang artinya:

“....Sesungguhnya Allah SWT telah menolongnya (M uhammad), (yai tu) ketika orangorang kafir mengusirnya dari Makkah, sedang dia adalah salah seorang dari dua orang ketika keduanya berada di dalam gua.." .

Secara keseluruhan, Allah SWT. menjelaskan 30 bilangan berbeda dalam Al-Qur'an, yaitu 1, 2, 3, 4, 5, 6, 7, 8, 9, 10, 11, 12, 19, 20, 30, 40, 50, 60, 70, 80, 99, 100, 200, 300, 1000, 2000, 3000, 5000, 50000, dan 100000. Bilangan-bilangan tersebut adalah contoh bilangan bulat.

Bilangan bulat terdiri dari bilangan bulat positif, bilangan bulat 0 , dan bilangan bulat negatif, agar kalian lebih memahami, perhatikan gambar di bawah ini:

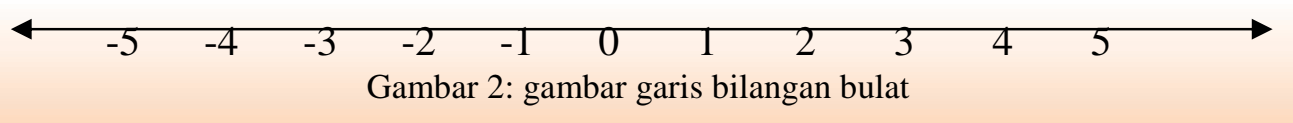

Bilangan yang berada di sebelah kanan 0 pada gambar garis bilangan bulat di atas disebut bilangan bulat positif, sedangkan bilangan yang berada di sebelah kiri 0 disebut bilangan bulat negatif. Maka yang harus kalian ingat bahwa: bilangan bulat terdiri dari bilangan bulat negatif, 0 , dan bilangan bulat positif. 


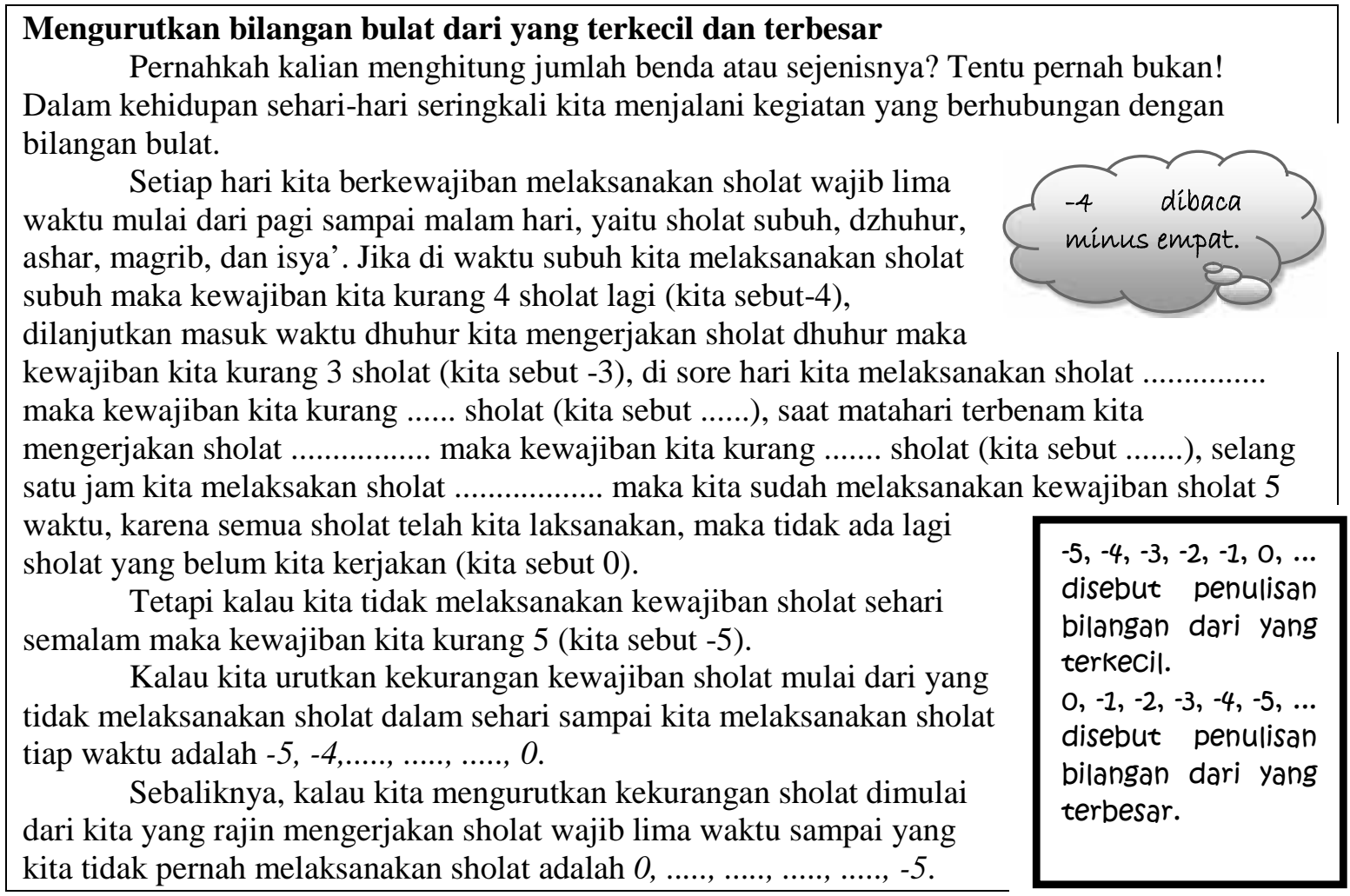
Gambar 3. Contoh Buku Ajar

Berdasarkan analisis data diperoleh hasil bahwa buku ajar dalam pembelajaran matematika dengan memasukkan nilai-nilai islami yang telah dikembangkan termasuk dalam kategori valid yaitu 3,65 serta memenuhi kriteria kepraktisan.

\section{Efektivitas Proses Pembelajaran}

Data aktivitas guru selama mengelola pembelajaran matematika dengan memasukkan nilainilai islami yang telah diamati oleh pengamat selama tiga kali pertemuan dapat dilihat pada tabel berikut:

Tabel 2. Hasil Pengamatan Aktivitas Guru

\begin{tabular}{|c|c|c|c|c|c|c|c|}
\hline \multirow[b]{2}{*}{ No. } & \multirow[b]{2}{*}{ Aspek yang diamati } & \multicolumn{3}{|c|}{ Pertemuan ke } & \multirow{2}{*}{$\begin{array}{c}\text { Rata- } \\
\text { rata }\end{array}$} & \multirow{2}{*}{$\begin{array}{l}\text { Rata-rata } \\
\text { tiap } \\
\text { kategori }\end{array}$} & \multirow{2}{*}{$\begin{array}{c}\text { Rata-rata } \\
\text { tiap } \\
\text { aspek }\end{array}$} \\
\hline & & I & II & III & & & \\
\hline \multirow[t]{4}{*}{1.} & Persiapan & & & & & 3,89 & 3,89 \\
\hline & $\begin{array}{l}\text { a. Rencana Pelaksanaan } \\
\text { Pembelajaraan }\end{array}$ & 3 & 4 & 4 & 3,67 & & \\
\hline & b. Buku Ajar & 4 & 4 & 4 & 4.00 & & \\
\hline & c. Lembar Kerja Siswa & 4 & 4 & 4 & 4,00 & & \\
\hline \multirow[t]{4}{*}{2.} & Pelaksanaan & & & & & & 3,53 \\
\hline & $\begin{array}{l}\text { 1. Pendahuluan } \\
\text { a. Membuka pelajaran dengan } \\
\text { salam dan berdo'a bersama }\end{array}$ & 4 & 4 & 4 & 4,00 & 3,78 & \\
\hline & $\begin{array}{l}\text { b. Mengabsen siswa serta } \\
\text { menyampaikan indikator } \\
\text { pelajaran }\end{array}$ & 3 & 4 & 4 & 3,67 & & \\
\hline & $\begin{array}{l}\text { c. Memotivasi siswa dengan } \\
\text { membacakan ayat al-Quran }\end{array}$ & 3 & 4 & 4 & 3,67 & & \\
\hline
\end{tabular}


a. Membagikan buku ajar

b. Memberikan gambaran umum tentang materi pelajaran pada buku ajar

c. Memberikan kesempatan siswa untuk membaca dan memahami materi yang terdapat pada buku ajar

d. Memberikan kesempatan bertanya tentang kejelasan materi

Tahap 2: Belajar dalam kelompok

a. Mengorganisasikan siswa dalam kelompok heterogen

b. Membagikan LKS sebagai panduan kerja kelompok

c. Memberi kesempatan siswa untuk membaca dan memahami masalah pada LKS

d. Memberi kesempatan siswa untuk bertanya tentang kejelasan masalah pada LKS

e. Memberi kesempatan kepada siswa untuk menyelesaikan masalah

Tahap 3: Penilaian

a. Meminta beberapa orang siswa mewakili kelompoknya untuk menampilkan hasil pekerjaannya di depan kelas

Tahap 4: Pengakuan tim

a. Mendorong kelompok lain untuk memberikan tanggapan terhadap hasil pekerjaan kelompok yang maju ke depan dan memberi penghargaan terhadap kelompok yang hasil pekerjaannya paling bagus

\section{Penutup}

a. Membentuk sesi tanya jawab

b. Menyampaikan informasi tentang pelajaran yang akan dipelajari pada pertemuan selanjutnya

3. Pengelolaan waktu

3,67

3,67

3,67

$\begin{array}{llll}4 & 4 & 4 & 4,00\end{array}$

$\begin{array}{llll}3 & 4 & 4 & 3,67\end{array}$

$\begin{array}{llll}3 & 4 & 4 & 3,67\end{array}$

$\begin{array}{llll}4 & 4 & 4 & 4,00\end{array}$

$\begin{array}{llll}3 & 4 & 4 & 3,67\end{array}$

$\begin{array}{llll}3 & 4 & 4 & 3,67\end{array}$

$\begin{array}{llll}3 & 4 & 3 & 3,33\end{array}$

$\begin{array}{llll}3 & 3 & 3 & 3,00\end{array}$

$\begin{array}{llll}3 & 3 & 3 & 3,00 \\ 3 & 4 & 3 & 3,33\end{array}$

3,17

2,67

Berdasarkan tabel di atas dapat dilihat bahwa rata-rata keseluruhan hasil pengamatan aktivitas guru selama mengelola pembelajaran matematika dengan memasukkan nilai-nilai islami sebesar 3,36. Sehingga dapat dikatakan bahwa aktivitas guru selama mengelola pembelajaran matematika dengan memasukkan nilai-nilai islami termasuk dalam kategori baik, maka aktivitas guru selama mengelola pembelajaran dikatakan efektif. Aspek pengelolaan waktu termasuk kategori "cukup" dengan ratarata 2,67. Hal ini dikarenakan guru dalam mengelola waktu ada yang tidak sesuai dengan rencana yang dibuat. Seperti pada RPP pertemuan ketiga dalam kegiatan memberi kesempatan siswa untuk menyelesaikan masalah serta mendisusikan/membandingkan (memeriksa, memperbaiki, dan 
menyeleksi) jawaban dengan teman sekelompoknya, guru membutuhkan waktu lebih lama. Karena ketika waktu habis dan LKS harus dikumpulkan banyak yang belum selesai, sehingga terpaksa guru harus menambahi waktu beberapa menit.

Pengamatan aktivitas siswa juga dilakukan sebanyak 3 kali dan setiap kali pertemuan 2x35 menit. Pengamatan aktivitas siswa ini dilakukan pada kelompok dan siswa tertentu untuk semua aktivitas. Hasil pengamatan aktivitas siswa adalah sebagai berikut:

Tabel 3. Hasil Pengamatan Aktivitas Siswa

\begin{tabular}{|c|c|c|c|c|c|c|}
\hline \multirow{3}{*}{ No } & \multirow{3}{*}{ Kategori yang diamati } & \multicolumn{5}{|c|}{ Persentase } \\
\hline & & \multicolumn{3}{|c|}{ Pertemuan ke } & \multirow[t]{2}{*}{ Rata-rata } & \multirow{2}{*}{$\begin{array}{l}\text { Jumlah tiap } \\
\text { kategori }\end{array}$} \\
\hline & & I & II & III & & \\
\hline \multirow[t]{5}{*}{1.} & & egori A & ivitas A & Siswa & & \multirow{5}{*}{63,33} \\
\hline & $\begin{array}{l}\text { 1. Bekerjasama dalam kelompok } \\
\text { untukmenyelesaikan/menemuk } \\
\text { an cara dan jawaban masalah }\end{array}$ & 13,75 & 16,25 & 15,00 & 15,00 & \\
\hline & $\begin{array}{l}\text { 2. Menulis yang relevan } \\
\text { /mengerjakan masalahyang } \\
\text { diberikan oleh guru }\end{array}$ & 13,75 & 11,25 & 12,50 & 12,50 & \\
\hline & $\begin{array}{l}\text { 3. Berdiskusi, bertanya, } \\
\text { menyampaikan pendapat/ide } \\
\text { pada teman atau guru }\end{array}$ & 22,50 & 26,25 & 27,50 & 25,41 & \\
\hline & $\begin{array}{l}\text { 4. Menarikkesimpulan suatu } \\
\text { prosedur/konsep }\end{array}$ & 10,00 & 10,00 & 11,25 & 10,42 & \\
\hline \multirow[t]{4}{*}{2.} & \multicolumn{5}{|c|}{ Kategori Aktivitas Pasif Siswa } & \multirow{4}{*}{36,67} \\
\hline & $\begin{array}{l}\text { 1. Mendengarkan/memperhatikan } \\
\text { penjelasan guru/teman }\end{array}$ & 16,25 & 13,75 & 12,50 & 4,17 & \\
\hline & $\begin{array}{l}\text { 2. Membaca/memahami masalah } \\
\text { yang ada pada buku ajar/LKS }\end{array}$ & 15,00 & 12,50 & 10,00 & 2,50 & \\
\hline & $\begin{array}{l}\text { 3. Perilaku siswa yang tidak } \\
\text { relevan dengan KBM }\end{array}$ & 8,75 & 10,00 & 11,25 & 10,00 & \\
\hline
\end{tabular}

Berdasarkan tabel 3 dapat dilihat rata-rata Persentase aktivitas aktif siswa sebanyak 63,33\%, sedangkan rata-rata Persentase aktivitas pasif siswa sebanyak 36,67\%. Karena Persentase aktivitas siswa yang aktif lebih besar dari pada Persentase aktivitas siswa pasif, maka aktivitas siswa dalam pembelajaran matematika dengan memasukkan nilai-nilai islami dikatakan "aktif". Tabel di atas juga menunjukkan bahwa aktivitas aktif siswa yang mendapat rata-rata paling sedikit adalah menarik kesimpulan suatu prosedur/konsep yaitu sebesar 10,42\%. Hal ini dikarenakan siswa masih belum terbiasa dengan pembelajaran ini, sehingga mereka merasa cukup kesulitan ketika akan menyimpulkan suatu konsep dari nilai-nilai islam yang telah diberikan sebagai contoh.

Respon siswa terhadap pelaksanaan pembelajaran matematika dengan memasukkan nilai-nilai islami adalah "positif". Hal ini disebabkan Persentase rata-rata respon positif siswa lebih besar dibandingkan respon negatif, yaitu sebesar $80,56 \%$, sedangkan Persentase rata-rata respon negatif siswa sebesar $19,44 \%$, seperti terlihat pada tabel 4 berikut

Tabel 4. Hasil Angket Respon Siswa

No. Aspek yang dinilai Persentase respon siswa (\%)


Senang

1. Bagaimana perasaanmu setelah membaca buku ajar?

2. Bagaimana perasaanmu selama mengerjakan LKS?

3. Bagaimana perasaanmu terhadap?

a. Kerjasama dalam kelompok

b. Suasana belajar dalam kelas

4. Bagaimana pendapatmu tentang cara memahami buku ajar?

5. Bagaimana pendapatmu tentang soalsoal yang diberikan?

6. Apakah kamu mengerti kalimat-kalimat yang ada di buku ajar?

7. Apakah dalam buku ajar terdapat nilainilai islami/agama islam?

8. Apakah menurutmu tampilan buku ajar ini menarik?

9. Apakah belajar dengan buku ajar ini bisa memudahkanmu memahami materi bilangan bulat?

10. Apakah kamu mengerti kalimat-kalimat yang ada pada LKS?

11. Apakah dalam LKS terdapat nilai-nilai islami/agama islam?

12. Apakah menurutmu tampilan LKS ini menarik?

13. Bagaimana pendapatmu jika materi selanjutnya menggunakan metode pembelajaran seperti ini?

Rata-rata
100

83,33

75

41,67

Mudah

Sulit

69,44

30,56

69,44

30,56

Ya

Tidak

77,78

88,89

11,11

91,67

80,56

19,44

75

88,89

11,11

91,67

8,33

\begin{tabular}{cccc}
$\begin{array}{c}\text { Sangat } \\
\text { setuju }\end{array}$ & Setuju & $\begin{array}{c}\text { Kurang } \\
\text { setuju }\end{array}$ & $\begin{array}{c}\text { Tidak } \\
\text { setuju }\end{array}$ \\
58,33 & 36,11 & 5,56 & 0 \\
80,56 & & 19,44 \\
\hline
\end{tabular}

Analisis hasil tes hasil belajar (THB) ditunjukkan pada tabel berikut:

Tabel 5. Hasil Belajar Siswa

\begin{tabular}{lcc}
\hline \multicolumn{1}{c}{ Uraian } & Banyak Siswa & Persentase \\
\hline Siswa yang tuntas & 28 & $77,78 \%$ \\
Siswa yang tidak tuntas & 8 & $22,22 \%$ \\
\hline
\end{tabular}

Dalam penelitian ini sebanyak 8 siswa tidak tuntas dan sebanyak 28 siswa tuntas. Hal ini dikarenakan dalam pembelajaran matematika dengan memasukkan nilai-nilai islami tidak hanya belajar cara pengerjaan soal dengan rumus atau konsep yang sudah tersedia, namun siswa merasa soal-soal materi pokok bilangan bulat lebih mudah dikerjakan dengan contoh dan konsep nilai-nilai islami yang telah ditanamkan pada diri mereka dalam kehidupan sehari-hari. Sehingga pembelajaran lebih bermakna bagi siswa. Tabel 5 di atas menunjukkan bahwa hasil belajar siswa telah memenuhi kriteria keefektifan.

Berdasarkan penjelasan di atas maka perangkat pembelajaran yang telah dikembangkan ini efektif bila digunakan dalam proses pembelajaran matematika pada materi bilangan bulat. 


\section{PENUTUP}

Berdasarkan hasil analisis data dapat disimpulkan bahwa perangkat pembelajaran matematika dengan memasukkan nilai-nilai Islami pada materi pokok Bilangan Bulat di kelas IV MI Mambaul Ulum Terik Krian Sidoarjo adalah valid, praktis dan efektif. Kevalidan RPP sebesar 3,93, kevalidan buku ajar sebesar 3,65, dan kevalidan LKS sebesar 3,73. Perangkat pembelajaran memenuhi kriteria praktis dengan rata-rata sebesar 3. Sedangkan kriteria keefektifan dipenuhi karena rata-rata hasil pengamatan aktivitas guru selama mengelola pembelajaran sebesar 3,36 sehingga dapat dikatakan bahwa aktivitas guru termasuk dalam kategori baik, rata-rata Persentase aktivitas aktif siswa sebanyak 63,33\% sedangkan rata-rata Persentase aktivitas pasif siswa sebanyak 36,67\% maka aktivitas siswa dalam pembelajaran matematika dengan memasukkan nilai-nilai islami dikatakan "aktif", tes hasil belajar siswa menunjukkan sebanyak $77,78 \%$ siswa tuntas, dan diperoleh Persentase rata-rata respon positif siswa sebesar $80,56 \%$ sedangkan Persentase rata-rata respon negatif siswa sebesar $19,44 \%$ sehingga dapat dikatakan bahwa respon siswa terhadap pelaksanaan pembelajaran matematika dengan memasukkan nilai-nilai islami adalah "positif".

Oleh karena itu perangkat yang telah dikembangkan ini dapat dijadikan alternatif yang baik dalam mengajarkan materi bilangan bulat sekaligus dapat membantu menanamkan nilai-nilai Islami dalam kehidupan siswa.

\section{DAFTAR RUJUKAN}

Abdussakir. 2009. Matematika 1 (Kajian Integratif Matematika \& Al-Q ur'an). Malang: UIN Malang Press.

Hayana, Nur. 2011. Pengembangan Model Pembelajaran Berbasis Masalah dengan Pendekatan Matematika Realistik pada Materi Himpunan di SMP Negeri 3 Waru Sidoarjo. Skripsi Tidak Diterbitkan. Surabaya: Jurusan Pendidikan Matematika IAIN Sunan Ampel Surabaya. http://alilmu.wordpress.com/2007/04/13/mukhtashar-ulumil-quraan, diakses 14 Januari 2013. $\mathrm{http} / /$ hajisunaryo.com/component/content/article/62-definisi-al-quran-dan-nama-nama-lain-dari-alquran.html., diakses 5 Februari 2013

Mushaf Sahmalnour.

Sanjaya, Wina. 2008. Strategi Pembelajaran. Jakarta: Kencana.

Sumaryono, Ihsan Wakhid. 2011. Pengembangan Perangkat Pembelajaran Matematika Realistik untuk Melatihkan Kemampuan Berpikir Kritis. Skripsi Tidak Diterbitkan. Surabaya: Jurusan Pendidikan Matematika IAIN Sunan Ampel Surabaya.

www.muslimah-rohis.blogspot.com. 2007, diakses 5 Februari 2013 